\title{
Konsep Diri Dalam Toleransi Stres Wanita Menopause Usia 40-59 Tahun di Sleman Yogyakarta
}

\author{
Dwi Widiyaningsih, Citra Diana \\ Sekolah Tinggi Ilmu Kesehatan Surya Global Yogyakarta
}

\begin{abstract}
Abstrak
Latar belakang: Menopause menyisakan keluhan psikologis diantaranya adalah penerimaan menopause yang kurang baik dan kurangnya kesiapan menghadapinya yang menyebabkan stress dan depresi. Stres pada wanita menopause dapat diatasi dengan konsep diri yang baik, 6 dari 10 perempuan menopause mengalami percaya diri yang kurang, tidak menghargai diri sendiri dan berpenampilan tidak sesuai dengan identitas diri. Semua komponen tersebut merupakan konsep diri yang rendah akibat beban stres yang mereka alami. Penelitian ini bertujuan untuk mendeskripsikan hubungan konsep diri dengan toleransi stress pada wanita menopause di Dusun Ngaglik Desa Caturharjo Sleman Yogyakarta.

Metode: Desain penelitian ini merupakan survei analitik dan menggunakan pendekatan cross sectional yang diambil selama bulan Maret 2019. Sampel penelitian sebanyak 49 wanita menopause yang dipilih dengan kriteria dalam purposive sampling. Analisis data menggunakan uji chi square.

Hasil: Sebagian besar responden memiliki konsep diri rendah (63,3\%) dan memiliki toleransi stres kurang baik (67,3\%). Hasil penelitian juga menunjukkan adanya korelasi yang bermakna terkait konsep diri dengan toleransi stres pada wanita menopause (nilai $\rho=0,0001)$.

Kesimpulan: Sehingga dapat dikatakan bahwa toleransi stress wanita yang sudah menapause ada keterkaitan yang kuat dengan konsep diri.
\end{abstract}

Kata kunci: Konsep diri, Menopause, Toleransi stres

\section{Self-Concept with Stress Tolerance in Menopause Age 40-59 Years Women in Sleman Yogyakarta}

\begin{abstract}
Background: Menopause leaves psychological complaints, namely poor acceptance of menopause and lack of readiness to face it which causes stress and depression. Office of menopausal women can cope with a good selfconcept, 6 out of 10 menopausal women experience lack of self-confidence, do not respect themselves and do not conform to self-identity. All of these components are low self-concept due to the stress they experience. This study aimed to describe the relationship between self-concept and stress tolerance in menopausal women in Ngaglik Hamlet, Caturharjo Village, Sleman Yogyakarta.

Methods: The research was a analytical survey and use cross sectional approach during March 2019. Sample were 49 menopause women are part of purposive sampling criteria. Chi square was used to analyze the data.

Results: Most of the respondents show that have a low low self-concept $(63,3 \%)$ and bad stress tolerance $(67,3 \%)$. There is a significant correlation between self concept and stress tolerance on menopause women ( $\rho$ value $=0,0001$ ).

Conclusion: So it can be said that stress tolerance of women who have reached menopause has a strong relationship with self-concept in Ngaglik Residence, Caturharjo Village, Special Region of Yogyakarta.

Keywords: menopause, self concept, stress tolerance
\end{abstract}

Korespondensi: Dwi Widiyaningsih

Email: widiya23juni@gmail.com 


\section{PENDAHULUAN}

CIA World Factbook menyebutkan perbandingan populasi laki-laki dan perempuan dewasa ini mencapai 101:100. Hal ini berarti jika laki-laki berjumlah 101 maka ada 100 wanita. Sementara usia harapan untuk hidup laki-laki yaitu 66 tahun, sedangkan wanita mencapai 70,8 tahun. ${ }^{1}$ Berdasarkan data tersebut dapat dikatakan bahwa jumlah penduduk wanita di dunia lebih banyak dikarenakan angka harapan hidup wanita di dunia lebih lama dibandingkan laki-laki.

Dengan bertambahnya usia harapan hidup dan meningkatnya status kependudukan wanita maka bertambah pula permasalahan yang terjadi pada wanita terutama masalah kesehatan. Pada masanya seorang wanita akan menghadapi satu fase dimana menurunnya fungsi seksual dengan mengalami menapause dimana kondisi semacam ini akan menjadi hal yang lumrah dalam rentang waktu 12 bulan artinya wanita akan mulai beradaptasi menerima hal tersebut rentang waktu 12 bulan. $^{2}$

Menopause pada wanita banyak menimbulkan berbagai problematika karena tidak semua wanita mampu menerima adanya menopause ditambah lagi dengan ketidaktahuan yang menimbulkan gejala stress karena mengalami "berhentinya" menstruasi. Stres yang dialami oleh wanita menopause akan menimbulkan berbagai macam permasalahan dalam psikologis diantaranya penurunan konsep diri wanita menopause. Ketidaktahuan akan apa yang harus dilakukan, pola pikir yang berubah terkait penerimaan diri membuat wanita semakin sulit untuk mengahadapi stres yang menimpa dirinya. ${ }^{3}$

Terjadinya perubahan fisik dan psikologis pada wanita saat datang fase menopause mengakibatkan adanya goncangan jiwa dimana muculnya rasa was-was, ketakutan, nervous bahkan merasa merana, sedih, gugup, lekas emosi, mudah tersinggung, stress dan tekanan mental yang semua itu akan mempengaruhi konsep diri yang ada pada wanita menopause. ${ }^{4}$ Sedangkan wanita dikatakan siap jika tingkat ketahanan stress mampu diredam sehingga ia memiliki kesiapan diri yang bagus hasil dari konsep diri yang positif, tentu hal ini juga tidak terlepas dari usia, dukungan suami, kepribadian, strata sosial, pendidikan dan juga pekerjaan. ${ }^{5}$

Pada tahun 2020 jumlah wanita yang hidup dalam usia menopause berkisar 30,3 juta atau setara dengan $15,3 \%$ dari seluruh populasi. Dengan rerata usia 49-53 tahun. Usia harapan hidup yang tinggi mengakibatkan peningkatan kejadian menopause pada wanita. ${ }^{6}$ Sekitar tahun 2025 jumlah wanita di Indonesia diprediksi yang akan mengalami menopause diperkirakan berjumlah 60 juta wanita. Sedangkan menurut WHO akan meningkat sebesar 1,2 miliar pada tahun $2030 .^{7}$

Badan Pusat Statistik memperkirakan pada tahun 2018, jumlah penduduk wanita di D.I Yogyakarta adalah 984.294 orang. Data menurut penduduk wanita distribusi umur 40-59 tahun dari lima Kabupaten di Yogyakarta jumlah penduduk wanita dengan distribusi umur 40-49 terendah berada di Kota Yogyakarta sebesar 55.195 penduduk wanita, sedangkan tertinggi berada di kabupaten Sleman sebesar 145.144 penduduk wanita. ${ }^{8}$

Menurut Data Sensus Kependudukan Desa Caturharjo Tahun 2017 jumlah penduduk wanita di Dusun Ngaglik Desa Caturharjo Kecamatan Sleman Kabupaten Sleman DIY sejumlah 374 jiwa dari total penduduk yaitu 706 jiwa. Mayoritas penduduk di Dusun Ngaglik adalah wanita, sehingga permasalahan pada wanita terutama masalah kesehatan menjadi lebih kompleks. Selain itu tidak adanya program komunikasi informasi dan edukasi (KIE) yang rutin di Dusun Ngaglik menjadikan semakin banyaknya mitos seputar kesehatan reproduksi wanita menjadi semakin banyak bermunculan terutama masalah terkait stres pada wanita menopause.

Berdasarkan studi pendahuluan pada 10 ibu di Dusun Ngaglik Desa Caturharjo Kecamatan Sleman Kabupaten Sleman, didapatkan hasil bahwa dari 10 ibu yang diwawancarai mengenai menopause (terkait konsep dirinya tentang menopause, gejala-gejala yang dialami serta bagaimana penerimaan diri terkait menopause), 4 ibu mengalami perasaan yang biasa saja tentang menopause, 6 ibu menjelaskan jika mereka merasa tidak percaya diri dengan tubuh mereka, merasa biasa saja tentang identitas diri (kurang menghargai diri sendiri), serta berpenampilan tidak sesuai dengan ideal diri mereka. Semua permasalahan tersebut menunjukan adanya konsep diri yang rendah. Hal tersebut akan sangat berkaitan dengan stress psikologis yang mana bisa membuat wanita menopause semakin tidak percaya diri dengan tubuh mereka akibat menopause hal ini sejalan dengan penelitian Sulisetyawati. ${ }^{9}$ 


\section{METODE}

Jenis penelitian yang digunakan adalah kuantitatif dengan metode penelitian survey analitik menggunakan pendekatan cross sectional. Populasi dalam penelitian ini wanita berusia 40-59 tahun sebanyak 93 orang. Teknik pengambilan sampel menggunakan kriteria dalam purposive sampling berjumlah 49 orang. Data dianalisis menggunakan uji chi square. Tempat penelitian ini berlokasi di Dusun Ngaglik Desa Caturharjo Kecamatan Sleman Kabupaten Sleman DIY. Penelitian ini dilaksanakan pada bulan Maret 2019 dengan variabel konsep diri sebagai variabel independen dan toleransi stres sebagai variabel dependen dengan derajad siginfikansi. Adapun instrumen yang digunakan adalah menggunakan kuesioner dengan $\mathrm{R}$ hitung $>\mathrm{R}$ tabel dengan alfa $5 \%$.

\section{HASIL}

Berdasarkan Tabel 1, mayoritas umur responden adalah 45-49 tahun sebanyak 19 orang $(38,8 \%)$ dengan umur terendah yaitu 40 44 tahun sebanyak 5 orang $(10,2 \%)$ dan umur tertinggi 55-59 tahun sebanyak 12 orang $(24,5 \%)$. Tingkat pendidikan responden mayoritas hanya tingkat dasar (SD) sejumlah 20 orang $(40,8 \%)$, sedangkan pendidikan D3 hanya 1 orang $(2,0 \%)$. Pekerjaan responden dominan sebagai ibu rumah tangga (IRT) sebanyak 28 orang $(57,2 \%)$, minoritas pekerjaan responden sebagai proyek bangunan dan guru masing-masing sebanyak 1 orang $(2,0 \%)$.

\section{Tabel 1. Distribusi Frekuensi Umur Responden}

\begin{tabular}{llll}
\hline Variabel & Kategori & Jumlah & $(\%)$ \\
\hline Kelompok umur40-44 & 5 & 10,2 \\
& $45-49$ & 19 & 38,8 \\
& $50-54$ & 13 & 26,5 \\
Pendidikan & $55-59$ & 12 & 24,5 \\
& SD & 20 & 40,8 \\
& SLTP & 17 & 34,7 \\
& SLTA & 9 & 18,4 \\
& SMK & 2 & 4,1 \\
& D3 & 1 & 2,0 \\
Pekerjaan & IRT & 28 & 57,2 \\
& Buruh & 14 & 28,6 \\
& Petani & 3 & 6,1 \\
& Pedagang & 2 & 4,1 \\
& Proyek & 1 & 2,0 \\
\hline Total & bangunan & 1 & 2,0 \\
\hline & Guru & 1 & 100,0 \\
\hline
\end{tabular}

Berdasarkan Tabel 2 dapat diketahui derajat kesalahan yang digunakan $\alpha=0,05$ dan $\mathrm{n}=49$ maka didapat nilai correlation coefficient yaitu $\mathrm{x} 2=26,547$ dengan nilai $\mathrm{P}=0,000$. Dengan hasil yang diperoleh ini menunjukan bahwa nilai signifikansi < nilai $\alpha \quad(p<0,05)$ maka Ho ditolak dan $\mathrm{Ha}$ diterima. Artinya terdapat korelasi yang bermakna antara variabel konsep diri dengan toleransi stress wanita menopause. Nilai korelasi chi square 26,547 lebih besar dari $\mathrm{x}^{2}$ tabel $(5,591)$, maka dapat diambil kesimpulan bahwa Ho ditolak dan $\mathrm{Ha}$ diterima. Artinya ada hubungan antara konsep diri dengan toleransi stress wanita menopause. Hubungan kedua variabel ini menunjukan arah korelasi positif (searah) artinya semakin rendah konsep diri wanita menopause maka semakin kurang baik pula toleransi stress wanita menopause.

\section{Tabel 2. Hasil Uji Korelasi}

\begin{tabular}{|c|c|c|c|c|c|c|c|}
\hline \multirow{3}{*}{ Konsep diri } & \multicolumn{4}{|c|}{ Toleransi stress } & \multirow{2}{*}{\multicolumn{2}{|c|}{ Total }} & \multirow{3}{*}{ P-value } \\
\hline & \multicolumn{2}{|c|}{ Kurang baik } & \multicolumn{2}{|c|}{ Baik } & & & \\
\hline & $\mathrm{n}$ & $\%$ & $\mathrm{n}$ & $\%$ & $\mathrm{n}$ & $\%$ & \\
\hline Rendah & 29 & 59,2 & 2 & 4,1 & 31 & 63,3 & 0,000 \\
\hline Sedang & 3 & 6,1 & 12 & 24,5 & 25 & 30,6 & \\
\hline Tinggi & 1 & 2,0 & 2 & 4,1 & 3 & 6,1 & \\
\hline Jumlah & 33 & 67,3 & 16 & 32,7 & 49 & 100,0 & \\
\hline$X^{2}=26,547$ & $\begin{array}{r}\alpha= \\
0,05\end{array}$ & & $\begin{array}{c}\mathrm{df}= \\
2\end{array}$ & & & & \\
\hline
\end{tabular}

\section{Menggunakan Chi Square Correlations}

\section{PEMBAHASAN}

Perempuan beranggapan bahwa ketika mengalami menopause perannya sudah selesai sebagai seorang istri dan ibu. Suami sibuk dengan pekerjaannya sehingga waktu untuk istri menjadi berkurang dan anak-anak dewasa sibuk dengan aktivitasnya. Terjadinya perubahan fisik dan psikologis pada wanita saat datang fase menopause mengakibatkan adanya goncangan jiwa dimana muculnya rasa waswas,ketakutan,nervous bahkan merasa merana, sedih, gugup, lekas emosi, mudah tersinggung, stress dan tekanan mental yang semua itu akan mempengaruhi konsep diri yang ada pada wanita tersebut. ${ }^{10}$

Sebagaimana yang di uraikan oleh Rahayu walaupun pra lansia berpengetahuan baik, tetapi pengetahuan saja tidak cukup untuk terbentuknya perilaku. Kemungkinan pra lansia memiliki tahap pengetahuan paling rendah yaitu 
"tahu" (hanya mengingat suatu objek) tidak sampai tahap pengetahuan paling tinggi yaitu "evaluasi" (kemampuan melakukan penilaian terhadap objek, misalnya menilai kondisi kesehatan. ${ }^{11}$

Temuan Parveen menjabarkan sikap yang kurang mendukung terjadi pada wanita yang tingkat pengetahuan tentang menapuse nya rendah. Dan kesiapan bagus dimiliki oleh mereka yang pengetahuan akan menapausenya baik. $^{12}$

Karakteristik responden berdasarkan umur dapat diketahu bahwa kelompok umur terendah dari responden adalah 40-44 tahun sebanyak 5 responden $(10,2 \%)$ dan tertinggi pada kelompok umur 45-49 tahun sebanyak 19 responden $(38,8 \%)$. Hal ini sejalan dengan Ceylan bahwa usia 40 tahun, wanita dianggap paling banyak mulai menhadapi menopause meskipun banyak juga faktor yang mempengaruhi usia menopause diataranya genetik dan gaya hidup. ${ }^{13}$

Responden dengan status ibu rumah tangga mempunyai andil 28 responden $(57,1 \%)$. mereka yang tidak bekerja namun mempunyai tugas dirumah dalam mengatur rumah tangga. Ibu rumah tangga (IRT) biasanya selalu berdiam dirumah dan jarang sekali mencari pengetahuan tentang kesehatan (menopause) ke suatu forum pertemuan untuk saling bertukar informasi. Sehingga pengetahuan mereka terkait menopause sangat minim, hal tersebut berpengaruh pula pada penerimaan diri mereka tentang menopause.

Menurut Khairiyah, pengelolaan stress yang berujung pada konsep diri seseorang akan sangat bergantng sekali pada karakteristik diantaranya usia, jenjang pendidikan, profesi dan kedudukan sosial serta karakteristik demografis yang dimiliki oleh responden sehingga berbeda wilayah akan berbeda konsep diri masing-masing meskipun diuji dengan instrumen yang sama. ${ }^{14}$

Dari hasil penelitian ini konsep diri responden yaitu mayoritas responden mempunyai konsep diri rendah sebanyak 31 responden $(63,3 \%)$. Bisa dikatakan bahwa responden tersebut mempunyai konsep diri yang negatif terkait kehidupan menopause yang mereka jalani. Menurut Tiarmy, konsep diri terdiri dari dua jenis yaitu konsep diri negatif dan konsep diri positif. Individu dengan konsep diri positif dapat mengetahui dirinya, menghargai dirinya dan menilai dirinya sendiri, dapat merancang tujuan dan memiliki keinginan besar untuk mencapai suatu pengharapan. Sedangkan individu dengan konsep diri negatif cenderung tidak bisa menerima dirinya, cemas dan takut menghadapi kegagalan, tidak mampu mengevaluasi diri dan bersikap pesimis. Individu yang memiliki konsep diri negatif bisa memiliki perasaan tidak stabil dan tidak teratur atau bahkan terlalu teratur. ${ }^{15}$

Menurut Subaryana Sementara untuk ciri-ciri dari orang yang memiliki konsep diri negatif, yaitu: tidak tahanterhadap kritik, kurang berani mengambil resiko terhadap tindakan, tidak tahan terhadap tekanan, mudah dipengaruhi orang lain, motivasi belajar dan bekerja yang rendah, menghindari peran sebagai pemimpin, takut akan kegagalan, tidak berani mengambil resiko, sulit untuk menyesuaikan diri dengan lingkungannya, mudah frustasi dan menimpakan kesalahan pada orang lain. ${ }^{16}$

Hal ini menjelaskan pada kita bahwa keberhasilan seseorang dalam kehidupan sosialnya sangat tergantung konsep dirinya sendiri. ermasuk hubungan kesehatannya sendiri terkait menopause. Seseorang yang menganggap bahwa menopause adalah suatu keadaan yang buruk dan membuatnya tak berdaya sehingga tidak bisa menerima menopause sebagaimana mestinya, keadaan ini lambat laun akan berpengaruh pada pandangannya dalam menjalani menopause dengan perasaan tertekan dan depresi sehingga menyebabkan konsep dirinya menjadi rendah. Konsep diri adalah gambaran dari pikiran kita tentang diri kita sendiri, oleh karena itu jika kita memandang diri kita rendah karena masa menopause, maka sikap kita menjalani masa menopause akan menjadi terganggu karena konsep diri kita terkait menopause adalah suatu ketidak-bahagiaan. ${ }^{17}$

Ditemukan 33 responden $(67,3 \%)$ dengan kesiapan toleransi stress yang kurang baik. Penerimaan menopause yang kurang baik bisa menyebabkan adanya ketidak-seimbangan antara pikiran dan penerimaan diri. Wanita menopause akan menimbulkan gejolak didalam dirinya yang membuatnya merasa khawatir dan stres. Apabila wanita menopause mampu mempertahankan ketahanan stress yang dia alami maka toleransi stress yang dia miliki adalah baik, sebaliknya jika tidak mengendalikan stress menopause maka toleransi stres mereka kurang baik. Menurut Dewi, toleransi terhadap stress dipengaruhi oleh usia, gender, personality, kecerdasan, emosi, status sosial atau status pekerjaan. ${ }^{18}$ 
Sejalan dengan penelitian Kurnia Dewi terdapat pengaruh langsung persepsi, konsep diri, dukungan keluarga dan kualitas hidup terhadap tingkat stress pada wanita menopause. Bahwa dukungan keluarga dan kualitas hidup dari wanita menopause merupakan faktor yang dominan yang sangat mempengaruhi tingkat stress pada wanita menopause. ${ }^{19}$

Dari studi ini diketahui bahwa terdapat korelasi konsep diri dengan toleransi stress pada wanita menopause. Subyek dengan nilai konsep diri rendah dan toleransi stress yang baik yaitu 2 orang $(4,1 \%)$, sedangkan yang memiliki konsep diri rendah dan toleransi stress kurang baik yaitu 29 orang $(59,2 \%)$. Melihat hasil persentasi diatas dapat disimpulkan bahwa wanita menopause dengan konsep diri rendah maka berpeluang besar mengalami toleransi stress kurang baik, sebaliknya wanita menopause dengan konsep diri tinggi akan berpeluang memiliki toleransi stress yang baik pula.

Hasil perhitungan korelasi chi square menunjukan nilai koefisien korealsi antara konsep diri dengan toleransi stress adalah 26,547 artinya lebih besar dari $x^{2}$ tabel yaitu 5,591 sehingga diambil simpulan $H o$ ditolak dan $\mathrm{Ha}$ diterima, maknanya ada korelasi antara konsep diri dengan toleransi stress wanita menopause. Hubungan kedua variabel ini menunjukan arah korelasi positif (searah) artinya semakin rendah konsep diri wanita menopause maka semakin kurang baik pula toleransi stress wanita menopause dan sebaliknya.

Kondisi mental yang dialami oleh wanita yang mengalami menapause bermacammacam mulai dari merasa kehilangan jati diri, kehormatan dan ketakutan akan ditinggalkan pasangan karena telah kehilangan fungsi sexualnya atau bahkan mereka akan memilki jiwa yang tearmat terguncang dan merasa diri kurang memilki arti dalam sebuah hubungan dan telah selsai perannya sebagai seorang wanita. ${ }^{9}$ Oleh karena hal tersebut maka konsep diri wanita menopause sangat berpengaruh pada stres yang mereka alami pada saat menopause.

Konsep diri yang rendah sangat erat kaitannya dengan pengetahuan yang rendah. Apabila melihat distribusi pendidikan responden mayoritas berpendidikan Sekolah Dasar maka dapat mempengaruhi daya tangkap informasi kesehatan yang dimiliki. Seseorang dengan pendidikan tinggi maka pengetahuan mereka akan jauh lebih baik, sehingga pola pencarian informasi tentang menopause akan lebih baik daripada mereka yang berpendidikan bawah. Sehingga kesiapan dalam menjalani menopause akan lebih maksimal, penerimaan yang baik, gambaran diri, citra diri, identitas diri, peran serta ideal diri mereka dalam menjalani masa menopause menjadi lebih siap sehingga tidak menimbulkan stress atau kekhawatiran dalam diri. $^{14}$

\section{KESIMPULAN}

Berdasarkan hasil penelitian dan pembahasan, maka dapat ditarik kesimpulan bahwa ada hubungan yang signifikan antara konsep diri dengan toleransi stress pada wanita menopause. Hubungan keduanya adalah positif yang mempunyai arti apabila konsep diri wanita menopause rendah maka akan diikuti dengan kurang baik pula toleransi stress mereka.

\section{DAFTAR PUSTAKA}

1. CIA. CIA World Factbook. 2016.

2. Lestary D. Seluk Beluk Menopause. Yogyakarta: Gerai Ilmu; 2010.

3. Aqila. Bahagia di Usia Menopause. Yogyakarta: A Plus Book; 2010.

4. Mulyani. Menopause Akhir Siklus Menstruasi pada Wanita di Usia Pertengahan. Yogyakarta: Nuha Medika; 2013.

5. Maramis W. Ilmu Kedokteran Jiwa Edisi

6. Kementerian kesehatan Republik Indonesia. Data dan Informasi profil Kesehatan Indonesia 2018. 2018;

7. WHO. Pusat Informasi Data Kesehatan. 2015.

8. Badan Pusat Statistik. Statistik Penduduk Lanjut Usia. Stat Pendud Lanjut Usia di Indones 2019. 2019; xxvi + 258 halaman.

9. Sulisetyawati SD. Dampak Menopause terhadap Konsep Diri Wanita yang Mengalami Menopause di Kelurahan Trengguli Kecamatan Jenawi Kabupaten Karanganyar. J KesMaDaSka. 2011;2(1):9-16.

10. Hekhmawati S. Gambaran perubahan fisik dan psikologis pada wanita menopause di posyandu desa pabelan. 2016;

11. Rahayu C, Widiati S, Widyanti N. Hubungan antara Pengetahuan, Sikap, dan Perilaku terhadap Pemeliharaan Kebersihan Gigi dan Mulut dengan Status Kesehatan Periodontal Pra Lansia di Posbindu Kecamatan Indihiang Kota Tasikmalaya. Maj Kedokt Gigi Indones. 
2014;21(1):27.

12. Parveen. Evaluation of knowledge of perception and coping strategis of perimenopausal women through self instructural module. Int J Sci Technol Res. 2012;

13. Ceylan. Factor Affecting Age Of Onset Of Menopause Addetermination Of Quality Of Life In Menopause. J Turkey Soc Obs Gynecol. 2014;1:4-9.

14. Khairiyah. Hubungan Antara Konsep Diri dengan Toleransi Stres Pada Wanita Menjelang Menopause di Pedukuhan I Geblakan , Kelurahan Tamantirto , Kecamatan Kasihan, Kabupaten Bantul TOLERANSI STRES PADA WANITA MENJELANG MENOPAUSE DI PEDUKUHAN I GEBLAKAN , KELURAHAN TA. 2008;

15. Tiarmy A, Giyono, Utaminingsih D. MENGURANGI KONSEP DIRI NEGATIF MENGGUNAKAN ASSERTIVE TRAINING PADA SISWA KELAS X SMA. 2015;

16. Subaryana. Konsep diri dan prestasi belajar. J Din Pendidik Dasar. 2015;7(2):21-30.

17. Marettih AKE. KUALITAS HIDUP PEREMPUAN MENOPAUSE. 2010;

18. Dewi KS. Buku Ajar Kesehatan Mental. 2012. 143 p.

19. Dewi MK. Pengukuran Empat Faktor yang Mempengaruhi Tingkat Stress pada Wanita Menopause. J Ilm Kebidanan Indones. 2018;8(03):144-56. 